\title{
Interdisciplinarity in Primary and Secondary School: Issues and Perspectives
}

\author{
Yves Lenoir, Abdelkrim Hasni \\ Faculty of Education, University of Sherbrooke, Quebec, Canada \\ Email: y.lenoir@videotron.ca
}

How to cite this paper: Lenoir, Y., \& Hasni, A. (2016) Interdisciplinarity in Primary and Secondary School: Issues and Perspectives. Creative Education, 7, 2433-2458. http://dx.doi.org/10.4236/ce.2016.716233

Received: July 31, 2016

Accepted: October 172016

Published: October 20, 2016

Copyright $\odot 2016$ by authors and Scientific Research Publishing Inc. This work is licensed under the Creative Commons Attribution International License (CC BY 4.0).

http://creativecommons.org/licenses/by/4.0/ (c) (i) Open Access

\begin{abstract}
The article deals with three questions which feed the debates on the school interdisciplinarity. Firstly, why promote interdisciplinarity in basic education? To answer this question requires to make a fast historical reminder of the emergence and the evolution of the interdisciplinarity in the field of education, so as to highlight three distinct readings of interdisciplinarity before presenting four arguments which show the relevance of its use in teaching. Secondly, how can interdisciplinary practices be fostered in education? The results of various works lead us to draw four strong trends, ideal-typical, to which the teachers use in their practices. Thirdly, what are the educational questions and issues raised by such practices, and what challenges must we address to make sure they are properly applied? We then suggest six principles by which to found and describe what we understand by school interdisciplinarity. A definition of the school interdisciplinarity is then moved forward. To conclude, we call back to mind a few aspects which appear essential when contemplating the use of interdisciplinarity in school, what leads us to place this one with regard to the transdisciplinarity.
\end{abstract}

\section{Keywords}

Interdisciplinarity, Transdisciplinarity, Primary and Secondary Education, Conceptions, Characteristics

\section{Introduction}

Over the past few decades, most of the new teaching curricula in the Western world from primary school up through university have advocated the use of interdisciplinarity, as shown, for example, by the 2010 special issue of the journal Issues in Integrative Studies (Lenoir \& Klein, 2010) as regards primary and secondary education in nine Anglophone, Francophone and Hispanic societies. In this article, we will examine interdis- 
ciplinarity only in connection with these last levels of instruction. The interested reader can consult Klein $(1990,1996,2002,2010)$ and Lenoir and Hasni (2010) for the taxonomy of interdisciplinarity to which we will be referring in this text as needed.

The three guiding questions of this article are as follows: Why promote interdisciplinarity in basic education? How can interdisciplinary practices be fostered in education? What are the educational questions and issues raised by such practices, and what challenges must we address to make sure they are properly applied? Indeed, good intentions are not enough: simply recognizing the need for interdisciplinarity in the face of contemporary social realities, or pointing to a paradigm of complexity (Morin, 1990), will not suffice.

To answer these three questions, as a refresher, we will begin with a sociohistorical overview. The intent will not be to give a detailed account of how interdisciplinarity emerged in the field of education or evolved over the 20th century. Instead, we wish, first, to highlight the existence of three different fundamental conceptions of interdisciplinarity in education, which, in our view, should be complementary. Second, we will set forth a number of arguments to justify the use of interdisciplinarity in basic education. Third, we will point out four unsatisfactory interdisciplinary trends that are nevertheless frequent in classrooms. These trends have emerged from a literature review, as well as analysis of teacher discourse and practices in the context of our researches. In contrast, we will give a first definition of interdisciplinarity in schools, or "school interdisciplinarity," which will be elaborated upon later in the text. Fourth, we will address the issue of applying interdisciplinarity in light of three aspects: firstly, we will distinguish between school interdisciplinarity and other fields of interdisciplinary application. Secondly, we will suggest six principles that should guide the implementation of interdisciplinarity in education. Of course, we will only have the space to mention what we consider to be the most important points in this regard. Thirdly, based on our previous characterization of school interdisciplinarity and these principles, we will present a descriptive definition of school interdisciplinarity, as a complement to the first characterization. Finally, in conclusion, this article will underline the importance of taking into account the purposes and the specificities of school subjects in any interdisciplinary classroom approach. It will then draw a link between the interdisciplinary and transdisciplinary perspectives while stressing the need, in education, to take into account common sense knowledge and practices that accompany ways of thinking and acting in everyday life; what is needed is to anchor teaching-learning situations in the complexity of life. Finally, the chapter will offer up a reflection on the evolution of curricula from an inter- or transdisciplinary perspective. Even if they must adapt to the realities and requirements of our times, the curricula in primary and secondary school should not fall into an exacerbated individualistic utilitarianism in their attempt to provide young generations with basic human and social education that is rich, diversified and open.

\section{Historical Perspective}

Interdisciplinarity has been a preoccupation of school systems since the end of the 19th 
century in the United States and has been the subject of numerous debates since then (Boix-Mansilla \& Lenoir, 2010; Klein, 1990; Kliebard, 1992). Only in the 1960s and 1970s, however, with the development of economic and cultural globalization, the internationalization of exchanges, and various social and economic pressures, did it significantly emerge in the European world (Ansart, 1990), and later still in the Spanishspeaking world (Fazenda, 1994, 1995; Miñana Blasco, 2001). This has been documented in particular by the articles published in the special issue edited by Lenoir and Klein (2010), which respectively provide a historical portrait of the emergence of interdisciplinarity in basic education in North America (United States, Ontario and Quebec), South America (Colombia), Europe (Spain, France and Switzerland), and Australia. While these articles may show that the conditions and circumstances under which interdisciplinarity emerged are different in each country, they also show that "the emergence of the concept can essentially be traced to two sources: government decisions and economic pressures in line with the requirements of a global market economy" (p. xi). They also suggest the existence of "a close link today between the competency-based approach and the recourse to the interdisciplinary perspective in curricula" (p. xi), a link which, moreover, is based on various epistemological foundations and/or neoliberal and/or utilitarian perspectives.

It is worth noting here that each society has approached the issue of interdisciplinarity in its school system in its own way, depending on its unique historical, political, cultural, social, educational, and other features. An anecdote eloquently attests to these different interpretations of educational realities. In 2002 a reform of initial teacher education was announced during a departmental assembly at the university where we work, in a context where the previous reform had not yet been completed and the new one was to be applied the following year. Several of our colleagues had the reaction, "What are we going to do?" This reaction left an impression on us. During a trip to France the following month, Professor Lenoir presented this issue to colleagues at the universities of Nantes and Toulouse. Their reaction was completely different. They asked, "Why the reform?" "How does it change the training content?" Two months later, Lenoir found himself at the Catholic Pontifical University of São Paulo where he had been invited by his colleague Ivani Fazenda. Her reaction and the reaction of her students to whom he had presented the same issue were still different: "Would I feel good in this reform?" These were three very different reactions to the same situation, already indicating the existence of distinct interpretations.

By more extensively examining the Anglophone North American and Francophone European perspectives (and, later, a certain Latin American and Brazilian perspective), we have been able to identify a series of factors that might explain the existence of distinct socio-historical logics and their underlying rationales. These logics can be illustrated based on a second real-life anecdote. In 2000, at an international conference, Professor Lenoir invited 32 researchers from various European countries (Belgium, France, Switzerland), North America (Canada, United States), and South America (Argentina, Brazil, Chili). The European participants extensively discussed the relevance of 
implementing interdisciplinarity, the meaning it should be given, and its impact on the hierarchy of scientific disciplines. Gordon Vars and Julie Klein then took the floor and wrote on a board to explain, in a few very systematic points, how interdisciplinarity can be operationalized. As for the Brazilians, they put on music and projected slides...

Although we must avoid over-generalization and caricature, these two concrete examples taken from direct experience, and supported by critical analysis of publications originating from these three cultures, show just how differently the notion of interdisciplinarity can be interpreted. We have been able to highlight the existence of three distinct logics (Figure 1) that result from sociohistorical and cultural factors (Lenoir, 1999, 2002, 2005; Lenoir \& Hasni, 2004; Lenoir, Hasni, \& Froelich, 2015; Lenoir, Rey, \& Fazenda, 2001). In Francophone Europe, and especially France, interdisciplinarity is strongly marked by rational Cartesian thought and the influence of philosophers (including Voltaire) and the Encyclopedists in the Enlightenment period. Hence, in this country, the search for meaning, rational logic, and consequently the epistemological perspective and the relationship to knowledge are central to interdisciplinary reflection. In the school context, the debate most often centers on protecting disciplines' specific identities, rather than forging interdisciplinary links (Durkheim, 1969; Stichweh, 1991). Socialization in the school context, for its part, is above all conceived as the transmission of cultural heritage in direct connection with a universalist vision consistent with the French Republican model ${ }^{1}$.

In the United States, which is dominated by an instrumental (pragmaticand organizational) educational perspective (Klein \& Newell, 1996; Newell, 2001), school interdisciplinarity is thought of as a search for operational answers to questions that arise within society. This focus on solving societal problems can be characterized as a "project” interdisciplinarity (Klein, 1990; Klein \& Newell, 1996; Lenoir, Hasni, \& Froelich, 2015) in which the knowledge involved is immediately useful and operational. In schools, the importance of know-how is clearly illustrated by publications that give operational methods for applying interdisciplinarity in class (e.g., Clarke \& Agne, 1997; Fogarty, 1991, 1993; Frazee \& Rudnitski, 1995; Jacobs, 1989; Pollard \& Tann, 1987; Tann, 1988; Vars, 1993). As noted in Lenoir, Hasni and Froelich (2015), "In the United States, the focus on the functionality of learning can betraced back to the pragmatism established at the end of the 19th century. This pragmatism should be associated with the preoccupation, dating to the same period, with placing the individual student at the heart of learning (the "subject pole"). Indeed, the need to socially integrate masses of immigrants necessitated a focus on pedagogical practices (to facilitate learning processes) and socialization processes (to foster civic skills). These two fundamental traits of the North American curricular conception have underpinned the professionalizing orientation of its education system. In the United States, the priority appears to be the adherence to the "virtues" and values of American society (personal

\footnotetext{
1"This French Republican tradition [...] posits state guaranteed non-domination as a definition of liberty, and is built on the foundation of individuals' ability to go beyond individual interests and adherences in order to work together in constructing an egalitarian political society" (Lenoir, Hasni, \& Froelich, 2015: p. 44).
} 


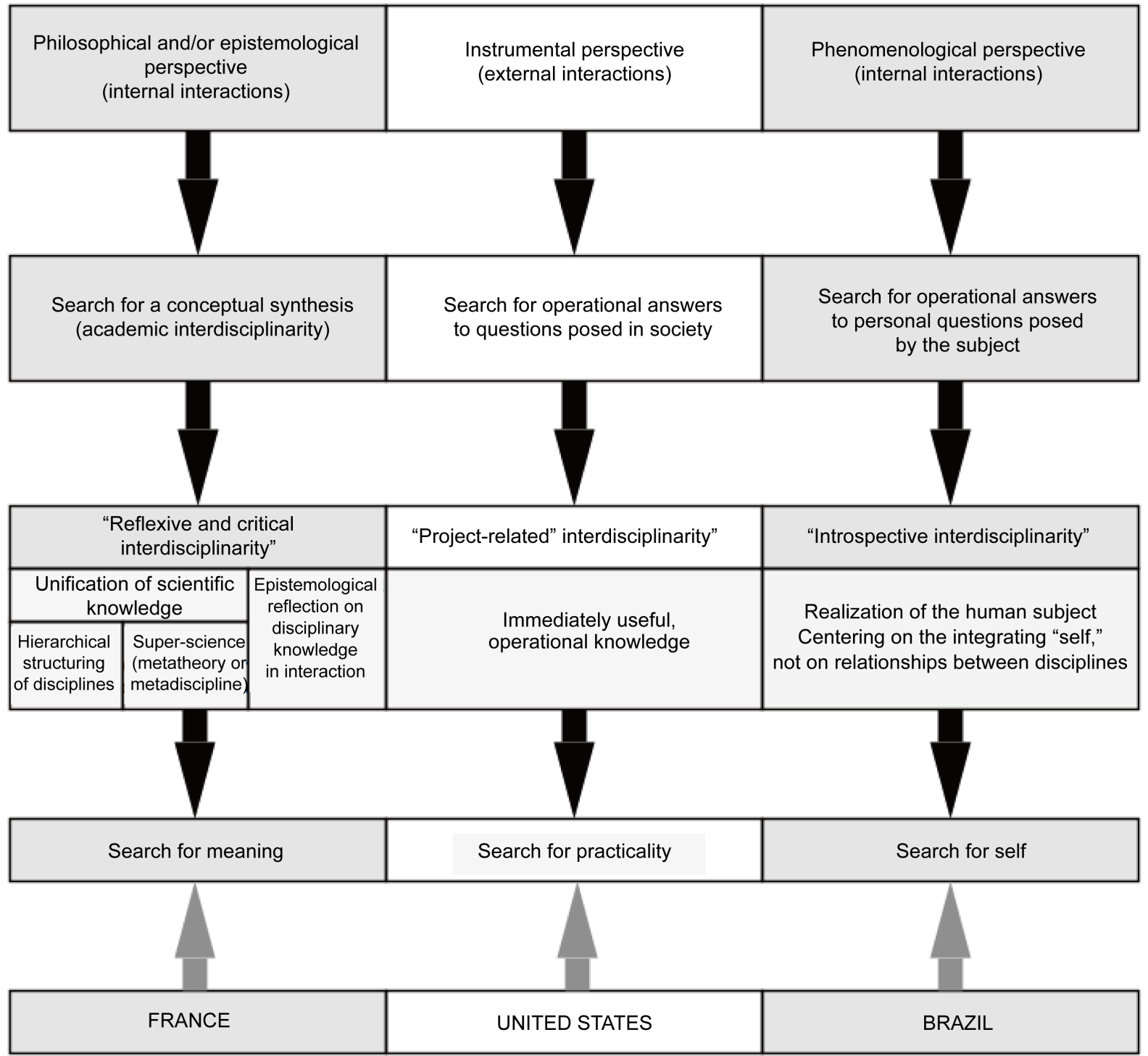

Figure 1. Three distinct readings of interdisciplinarity.

skills) as well as know-how geared toward problem solving" (p. 66). Hence, the French epistemological search for meaning stands in contrast to American functionality, even if this does not preclude the existence of other interdisciplnary currents in the school context (Lenoir, Hasni, \& Froelich, 2015).

In addition to these two distinct approaches to interdisciplinarity-one primarily involving knowledge and the other know-how and certain personal skills-it is important to acknowledge a third, which is strongly expressed in a certain Brazilian conception of interdisciplinarity. The perspective adopted in this case is clearly phenomenological and involves a symbolic interactionism. The emphasis is on the actor as a medium for interdisciplinarity, and therefore on the subjectivity of individuals who are integrated into everyday life and on their methodological intersubjectivity. The main concern is the process of continually constructing the individual in a situation, a proc- 
ess involving not only self-knowledge, but also knowledge of others (Fazenda, 1994, 1998). In the Brazilian logic, which is profoundly subjective (and intersubjective), school interdisciplinarity is mainly focused neither on a reflexive function with regard to knowledge, nor on a pragmatic function. The predominant aim is rather to pursue the realization of the human subject by stressing the integrating "I", not the relationships between disciplines, and even less functional and pragmatic action. From this affective perspective, interdisciplinarity above all has to do with the internal interactions of the subject, as he or she searches for answers to personal questions. The idea might be described as an introspective interdisciplinarity that is founded on a search for the self. We will come back to these three perspectives at the end of the following section in order to underscore the need for complementary relationships between these perspectives in school interdisciplinarity.

\section{Why Implement Interdisciplinarity in Basic Education?}

Why promote interdisciplinarity in basic education? By which arguments can it be justified? In other words, which aims can be pursued thanks to school interdisciplinarity, as opposed to monodisciplinarity which means the appeal to a single discipline?

Of course, in this regard, it is important to recognize the complexity of the natural, human, and social reality in which we live, as well as the fragmentation of the knowledge transmitted in schools. This perspective has been elaborately presented and described by Klein (2002), Morin (1977-1991, 1990), and Torres Santomé (1998), among others. We will merely note this central argument for interdisciplinarity in passing. But in the context of youth education, we would like to point out other arguments that directly bear on teaching-learning processes. These arguments are based on the fact that school learning takes place in a specific context, namely the physically closed space of the classroom, that is, a system of interactions among students and between the students and the teacher. We would thus consciously like to examine aspects that are less often considered when dealing with interdisciplinarity in general. Some of these are related to the four arguments that Klein (2002) suggests on an educational level: a profound transformation and restructuring of knowledge; educational reforms that have introduced new curricular connections with a view to integration; the focus on solving real-life problems; and the concern for developing critical thinking.

It is important to recall, first of all, that students 6 to 16 - 17 years old do not generally study out of a love for the school disciplines, but instead, one might say, out of a "love" for the teacher. More specifically, although we could not develop here the entire set of arguments that originally stemmed from dialectic Hegelian thinking and that has been developed by so many researchers, including Kojève (1947), Lacan (1966) and Honneth (2013) — and well before them by Spinoza (1842), who described it as the essence of human nature and the driver of action (the conatus) - the student strives to capture the desire to know that he/she decodes in the eyes, attitudes, and discourse of the teacher. The student's behavior in class is then dictated not by the need to know, but originally by social, intellectual, and affective relationships that he/she develops 
with the teacher with the intent of appropriating the qualities decoded in the teacher and obtaining recognition of value as a human being. A love of knowledge may develop only subsequently. The teacher's role is therefore crucial. An interdisciplinary approach in this context assumes an important function of facilitation; however, it will only do so insofar as it takes into account the following.

First, interdisciplinarity requires teaching-learning situations that are meaningful to students. The situation must be contextualized, and such a contextualization must necessarily be multi-dimensional, given that, to be understood the situation requires an interdisciplinary approach. Yet for many students, distinguishing between everyday life and school life is problematic.

Scholars such as Bernard Rey of the Université Libre de Bruxelles have observed misunderstandings that arise when students are confronted with a proposed situation. Let us take a real-life example: when Professor Rey, who had been invited to a classroom, asked students how to take the train to go home, the route to take, the distance, the duration of the trip (which required the use of mathematical and geographical knowledge), a student immediately answered him that he shouldn't worry, that his father was not working that day and would be pleased to drive him to the station on time. Joël Bisault (2011), of the École normale supérieure de Cachan à Paris, has likewise underlined problems of interpretation in school assignments among primary students by showing that some adopt a "domestic point of view." This misunderstanding has also been noted in other studies of classroom practices in Quebec. For example, a study of four teachers' instructionon plant parts (biology) shows that hypothetical situations that are strongly anchored in everyday life (an aunt's organization of a food shopping basket into fruits and vegetables) can be an obstacle to posing scientific problems. In this case, the students' interpretations of the situation led them to focus their verbal exchanges on their everyday knowledge of fruits (such as their sweetness and juiciness) or on men and women's culinary skills (use of fruits and vegetables) (Hasni, 2011).

There is a real trap that students can become engaged in exclusively relational, affective, domestic, and other readings of the situation if the contextualization remains superficial and incomplete. This problem persists in secondary school. We will come back to this problem when discussing the fourth point on the importance of contextualization. Suffice it to say that if contextualization is not adequately developed, there is a risk that students will differently interpret the instructions and tasks given by their teachers, because they will not decode the school task within the situation. The issue is with the student's task, as opposed to the child's or adolescent's task, that is expected of them, because they may perceive only the visible (external) facet of the task to complete. They might also be unable to assign meaning to the situation or the task itself (the internal context) and lose interest and motivation in the work that is expected; in short, they "disconnect." Indeed, this is one of the factors leading to a lack of interest in school and cases of dropout. In short, the interdisciplinary perspective in school fosters students' search for meaning, in terms of the knowledge (epistemological perspective), the subject (ontological perspective), and the engagement in life activities (social perspective) 
that are involved.

Second, because of the need to use varied disciplinary knowledge, interdisciplinarity calls for the use of what Boix-Mansilla (2010) refers to as a pragmatic constructionist epistemology. The fundamental raison d'être of such a pluralist epistemological concept is to promote and support students' construction of meaning. Precisely because students struggle to distinguish between everyday life and school life, between common sense learning and school-related learning, we believe it is necessary to use the springboard of teaching-learning processes that involve situations anchored in reality. This allows teachers to leverage students' life experiences, as well as the pragmatic notions and concepts that they use in their everyday lives and that are indispensable for organizing action. Vygotsky (Rieber \& Carton, 1987) had already established a link between everyday concepts and scientific conceptualization processes. Real-life situations allow students to invest themselves based on their life experiences, so that they can inter-subjectively debate their different conceptions, and then, with the teacher's help, progress toward the use of scientific approaches. Even if, in everyday life, students communicate, construct knowledge, solve problems, and carry out experiments, these different processes tend to come down to common sense. School should be a place where they make the transition from these processes acquired in everyday life to scientific approaches that involve a critical and well-considered objectivization of actions that are carried out systematically and explicitly: communicating, conceptualizing, problem-solving, and experimenting. To address only this last process, a distinction must be made between giving an opinion and conducting an experiment. This is why trial and error, and empirical efforts at understanding, are a point of departure that must be moved beyond from an integrative perspective. The interdisciplinary perspective precisely requires the interrelated use of a number of scientific processes.

Student action is therefore a point of departure, but also a stumbling block. Education must indeed focus on the need to apprehend a subject who is "capable," who can say "I can" or "I cannot," and not only epistemological subjects who "know," who master knowledge and who can say "I know" or "I do not know." Interdisciplinarity carries with this conception of an inseparable bond between cognition and functional action, for "I can" if "I know." Allow us to give a real-life example that illustrates the need to anchor teaching-learning processes in the realities of students. When Professor Lenoir was invited to a classroom by a teacher in order to do a science activity, Lenoir asked the students, based on the program objectives at the time, to design, draw, describe, and explain the production and functioning of an object that could make noise as it moved (thereby using science, technology, drawing, and French). The students worked in teams and one of them helped out most of these teams. However, before entering the classroom, the teacher had told Lenoir that the student who was helping all the others was the most difficult, the least cooperative; that was why he was seated at the back of the class. When Lenoir congratulated the student, who was one of the most pleasant and helpful during the entire activity, for his valuable help and the quality of guidance he gave to other students, he also asked how he had developed these skills. The student 
answered that his father was an engineer and that he liked to imitate him. This may have been a happy coincidence, yet interdisciplinarity clearly offers the possibility of giving meaning to learning activities.

A third contribution of interdisciplinarity in basic education has to do with the need for complementarity and overlap in the scientific processes to which we have just referred. Rather than naïvely or unconsciously-or neglectfully-employing only problem solving, interdisciplinarity can (among other things via a problem- or project-based approach) support the development of integrating learning processes. It is able to do so through the use of several approaches required by the necessary complementarity of diverse disciplinary outlooks, namely conceptualization, problem-solving, communicational, experimental, and other approaches. It also stresses the fact that problematization is central to a teaching/learning process, and that scientific approaches are cognitive processes that must in themselves be an object of learning. It is impossible, for instance, to produce an experiment protocol without having first conceptualized the experiment's components; and the results, for their part, require a communicational approach.

Fourth, and this point connects with the question of metacognition and the selfregulation of learning, interdisciplinarity is only genuinely meaningful if metacognitive processes are introduced and promoted by the teacher, and if they are applied by the students. What has been observed in everyday life is that teachers teach knowledge, sometimes by making links between different school disciplines, but they forget or neglect the metacognitive processes that are indispensable to ensure effective learning. While they are often led to ask students whether they enjoy an activity, and hence call upon affective dimensions, they forget the cognitive and procedural dimensions. Indeed, only rarely does one hear a teacher asking the students, "What have we just learned?" "How did we arrive at this knowledge?" "What pathway, what steps have we taken?" "What difficulties did we come up against?" "How did we resolve these difficulties?" etc. Students' initial representations need to be collected and held on to so that they can be referred to and compared during a culminating synthesis' activity, in order to take stock of the cognitive ground that has been covered.

The following example clearly illustrates this absence of a metacognitive process: in a class during last year of primary school, a teacher gave students an aerial photograph of their village. Several students immediately said that the picture was of Quebec. We will not describe all the activities held by the teacher, including a field trip to the village with direct observation, graphic representations, the production of texts, etc. Following these activities, the same students said, "We knew it all along, it's our village!" thereby forgetting their initial representations, which had not been collected. Moreover, the teacher had not given the students an opportunity to apply the metacognitive processes that would have allowed them to integrate both the procedural processes by which they had constructed the new knowledge and the knowledge itself. As a result, there was no guarantee that this knowledge had been acquired and that the capacity to reinvest it in the future had been developed. 
In the few points, we have just presented to justify the use of interdisciplinarity in basic education and to discuss a few of its aims. The reader will note that we have called upon the mind, the hand, and the heart, that is to say, the cognitive, pragmatic, and ontological dimensions.

\section{Interdisciplinary Conceptions and Practices That Are Inappropriate to the Teaching-Learning Process}

It is not enough to use the word "interdisciplinarity" for a given practice to accurately correspond to the concept. The many studies we have conducted for almost 30 years on teaching practices in Quebec have allowed us to identify Quebec teachers' representations of interdisciplinarity at school as well as its implementation in their teaching practices (Lenoir \& Hasni, 2010). The results of this research in schools have brought to light that interdisciplinarity exhibits a polysemy sometimes bordering on cacophony (Fourez, Maingain, \& Dufour, 2002). This polysemy is of little help in circumscribing the term's meaning(s) in terms of its scientific basis. The word is clearly fraught with incoherence that has led to errors and obscurities. The concept of interdisciplinarity is given multiple significations that create semantic confusion, to say the least, and ultimately practices that are not so interdisciplinary. Analysis over the past 30 years has identified four groups of conceptions and teaching practices in the school contextpseudo-interdisciplinary, hegemonic, eclectic and holistic-which show different degrees of proximity to the scientific foundations of school interdisciplinarity (Figure 2).

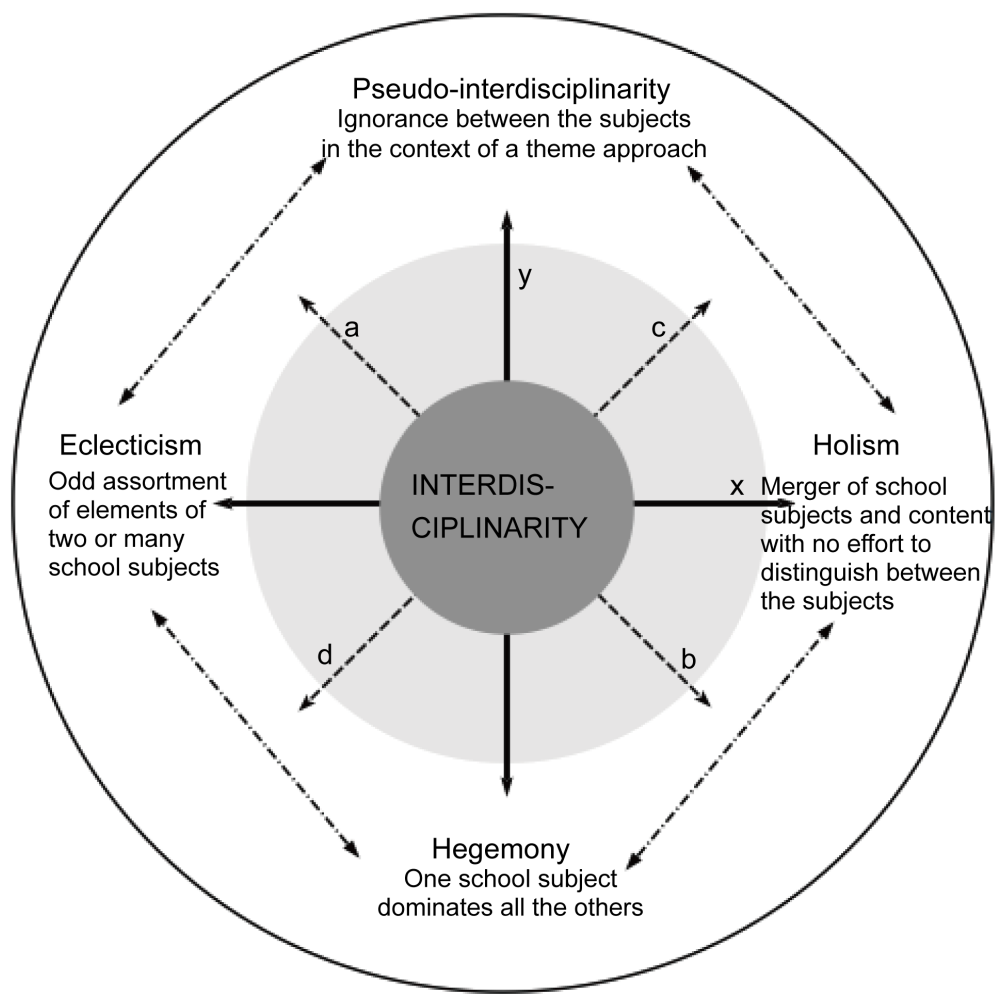

Figure 2. The poles of interdisciplinary practice. 
Placed on a cartesian axis ( $x$ and $y$ ), these four dominant approaches make up the extreme poles of two intersecting continua. The $x$ axis (holism-eclecticism) concerns the degree of fusion or dispersion of school disciplines, while the $y$ axis (hegemonypseudo-interdisciplinarity) concerns the intensity of relations between disciplines, ranging from domination to the absence of real links. The two-sided arrows $a c$ and $b d$ illustrate the fact that interdisciplinary practices can be associated with one approach or lie somewhere between two approaches. The circle at the center of the diagram represents the interdisciplinary perspective we will present further on.

The results of various research show that a theme-based pseudo-interdisciplinary is especially often preferred by first-cycle primary teachers. This tendency is mainly caused by their significant preoccupation with awakening student interest, in which case the relational and psycho-affective dimensions (together with the organizational dimension) take up a preponderant place in their interventions with students, to the detriment of cognitive dimensions. On the other side of the spectrum, the hegemonic approach, in which certain disciplines are in fact no more than a pretext for teaching other disciplines, may be explained by the priority certain teachers give to teaching the language of instruction. The eclectic approach, which is profoundly destructuring, since, to quote Jacobs (1989), it perceives learning content as a "pot-pourri" from which one can pick at random, is also commonly observed in teaching practices. The holistic approach, which is based on the negation of all disciplinary specificities in the name of a natural approach, is frequently observed among teachers adhering to pedagogical conceptions that promote an open and active pedagogy centered on student interest, thereby sidelining cognitive objectives. These four approaches are in some cases used by teachers whose primary aim is to meet curricular requirements from a strictly administrative point of view. When this happens, these approaches serve mostly as justifications for the absence or near-absence of the teaching of certain school disciplines that are officially mandatory and planned for in the program, but in fact considered secondary from a societal point of view. This situation especially applies to the teaching of the arts, natural sciences, and humanities. These different trends have been presented in Lenoir and Klein (2010). For example, pseudo-interdisciplinarity, if not eclecticism, can be found in Australia (Long, Moran, \& Harris, 2010) and eclecticism, along with the hegemonic perspective and holism, can be found in Colombia (Rodriguez \& Miñana Blasco, 2010). Likewise, the hegemonic perspective can be noted in teaching practices in Ontario (Clausen \& Drake, 2010). It has also been identified in an article by Baillat and Niclot on France (2010) and an article by Segovia, Lupiáñiez, Molina et al. on Spain (2010).

The discourse on interdisciplinarity therefore conceals practices most often marked by the primacy of certain socially valued disciplines and a dilution of the socialized knowledge of "secondary" disciplines, in favor of gaining time for the teaching of primary disciplines. Among many other results, we have highlighted the strong hierarchy of school disciplines. The reasons are not primarily school-related, but social, political, and ideological-economic. The importance of the disciplines does not, however, depend 
a priori on government discourse, which is also influenced by pressure from lobbies and social groups. Their importance depends on the value that society and institutions actually assign to them. In this vein, British sociology research [especially by (Bernstein, 1971a, 1971b) and (Young, 1971), who contrast a compartmentalized curriculum with an integrated one] underscores the intrinsic hierarchical character of a compartmentalized curriculum and the very powerful process of social seleection and control that it implies.

Moreover, it can be hypothesized that teachers' use of "interdisciplinary" practices is based on two key preoccupations: first, gaining time, and second, boosting student interest and motivation viathematic approaches or projects. The cognitive contributions ultimately receive little consideration. This state of affairs connects with the "practical logic" of Bourdieu (1980). Practices are "practical" in that they are "capable of producing intrinsically coherent practices" (p. 145) in a given situation, and in that they involve the principle of an economy of logic. In other words, they are simple and useful because they are based solely on a few generative principles that are strongly interrelated and impose the structuring of (and structuring within) action. In short, this logic-which we associate with the world of common sense-can be easily mastered, managed, and put into practice, thus requiring little time and energy.

In contrast to these different and more or less skewed interpretations, we consider that school interdisciplinarity postulates the establishment of mutual dependence, free of predominance or neglect, between school subjects. We will come back to this point. Such an epistemological, social, and political posture leads to a different reading of curricular components, one based on a search for the specific identity of each discipline (its place and function on the cognitive and social levels) as well as the complementarity of contents that is needed in order to apprehend, communicate, and relate to natural, human, and social reality. This posture also calls for a critical position toward the hierarchy of school disciplines and the resulting function of social selection. To return to the perspective developed by Bernstein, the "serial" (additive or cumulative) conception of curriculum implies opacity, rigidity, and hierarchy, while the "integrated" (we might say "integrative") conceptionpromoted by interdisciplinarity involves permanent interactiveness, a sharing of power between teachers and between teachers and students, and a necessary transparency about the aims and goals that are being pursued.

\section{The Specificity and Characteristics of School Interdisciplinarity}

To avoid falling into one or another of these four conceptions, which do not fully characterize what is expressed by school interdisciplinarty, we must first distinguish the concept from other forms of interdisciplinarity. We will then suggest six principles by which to found and describe what we understand by school interdisciplinarity.

\subsection{School Interdisciplinarity and Other Fields of Interdisciplinary Operationalization}

Interdisciplinarity, which, as we have mentioned, is a very polysemic notion, is imple- 
mented in a variety of fields of human activity based on distinct societal aims. When examining the aims pursued, the angle of approach to reality that is adopted, and the choice of subjects that are dealt with, we can distinguish four fields of interdisciplinary operationalization: academic interdisciplinarity, school interdisciplinarity, professional (or vocational) interdisciplinarity, and practical interdisciplinarity (Figure 3).

As Hermerén (1985) notes, all four fields of interdisciplinary operationalization can be approached, depending on the problems and preoccupations at hand, from three angles, namely organization, research, and teaching. We would like to add a fourth angle of approach, namely practice. In other words, in each field, interdisciplinarity can be investigated (research), taught (teaching), or put into practice (application). The matter of organizationin fact applies to all cases. According to Hermerén (1985), organizational issues directly influence teaching and research: all interdisciplinary activity, whether research, teaching or other, is confronted with the challenge of organization from various standpoints (institutional, interpersonal, structural, cognitive, etc.). A critical review of numerous studies (Hasni \& Lenoir, 2001), essentially in the United States, have looked into this problematic dimension of managing interdisciplinarity, especially in research, but also in teaching, revealing that socio-ideological issues and organizational problems in particular are the main obstacles to using interdisciplinarity in research and teaching. In sum, it is extremely important to clarify, from the outset, the goals pursued (the "why"), the target intended (the "whom"), and the subjects dealt with (the "what").

\subsubsection{Practical Interdisciplinarity}

Practical interdisciplinarity refers to the practical experience that an individual acquires and uses to solve everyday problems of managing individual and societal life. It is leveraged to addresspractical, technical, and procedural problems, and clearly stands apart from other operational fields of interdisciplinarity in the following ways:

- It is essentially based on experience that individuals have acquired or will acquire (experiential knowledge) in various areas or everyday situations.

- It is instrumental in nature and is applied to resolving problems and situations of daily life.

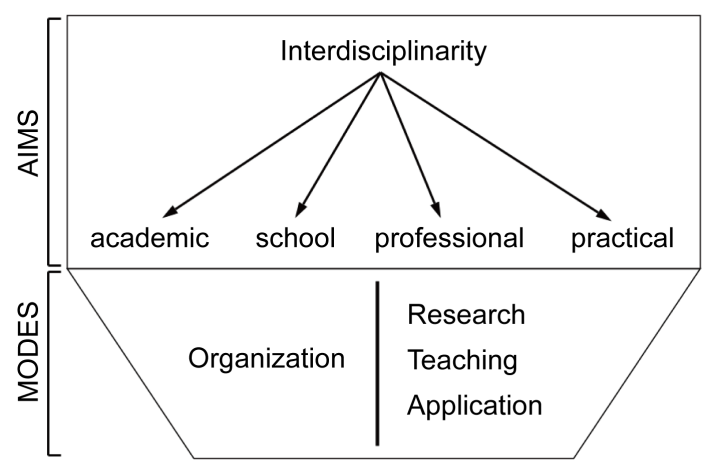

Figure 3. Fields of operationalization and angles of approach associated with interdisciplinarity. 
As a result, it appears as natural as the prose of Molière's famous would-be noble Monsieur Jourdain, as Fourez (1994) mentions: "when doing odd jobs or making hygiene-related choices, for example, we are constantly connecting elements from the natural sciences, issues of economy or ecology, and aesthetic choices" (p. 81). A mechanic repairing a car, a cook making mayonnaise, a gardener pruning plants, a speculator "playing" the stock market, or a bus driver driving his public vehicle all use procedural knowledge, experiential knowledge, and more or less routine and conscious practices from various horizons, including disciplinary, technical, and professional ones.

\subsubsection{Academic and School Interdisciplinarity}

Interdisciplinarity in the realm of the school ("school" interdisciplinarity) should be clearly distinguished from interdisciplinarity in the realm of scholarly research ("academic" interdisciplinarity), with regard to its aims, objects, application methods, and system of reference. The former requires major adjustments with regard to the latter. Too many attempts have been nothing more than direct transplantations from the scholarly context to the school. As is the case for many nomadic concepts (Stengers, 1987), a migration to other fields of application entails reinterpretations of meaning and changes in content and scope, which must be taken into account when dealing with interdisciplinarity. This is why, just as a distinction exists between a discipline in the scholarly context and a discipline (or school subject) in the school context, it is important to distinguish between "academic interdisciplinarity" and "school interdisciplinarity." Table 1 presents a few of the distinctions between these two fields of interdisciplinary operationalization. They are sufficiently clear, in our view, as to require no further commentary.

As a result, while recognizing that schooldisciplines are organized "according to a schema which is similar or analogous but not identical" (Sachot, 1993) to that of the academic disciplines, it is important to acknowledge that they have different aims, objects, methods of application, and references. It is therefore important to be very cautious when importing concerns and taxonomies from one domain to another, and to acknowledge this fundamental distinction.

\subsubsection{Professional Interdisciplinarity}

Professional (or vocational) interdisciplinarity, for its part, has to do with the integration of a set of processes and knowledge (academic and practical) to develop the skills and competencies required by a given occupation. It requires going beyond the usual characteristics of interdisciplinarity. Any professional training requires the integration of a set of approaches and knowledge geared toward the development of professional skills and competencies required by the given occupation. As a result, unless it is considered a more or less connected addition of disciplines, this training involves a basic interdisciplinary approach. Because the aim of training is to master a professional action, it is not enough to be able to establish links between academic disciplines; things need to move to another level that goes beyond disciplinary and interdisciplinary edu- 
Table 1. Differentiation between academic interdisciplinarity and school interdisciplinarity.

Academic interdisciplinarity
Is aimed at producing new knowledge and
responding to social needs:
- $\quad$ by making links between the branches of science -
- by establishing a hierarchy (ordering of academic
disciplines)
- by epistemological structuring
by understanding the different disciplinary
perspectives through via a re-establishment of
communication links between disciplinary
discourses

School interdisciplinarity

Aims

Is aimed at teaching academic knowledge and educating social actors:

Epistemological options

Relational perspective: establishment of

Relational perspective complementary, converging, and interconnecting links

Ampliative perspective: filling the gap observed between two existing sciences or between several sciences, thus leading to the emergence of new disciplines

Restructuring perspective: questioning the very nature of knowledge and promoting the emergence of a new conception and a new structure of academic knowledge to overcome their compartmentalization and "protective" boundaries

\section{Objects}

Academic disciplines

School disciplines

\section{Methods of application}

Involves the concept of research:

- takes knowledge as its system of reference
Involves the concept of teaching and education:

- takes the learning subject as its element of reference

\section{Reference system}

Addresses a discipline as a science (scholarly and certified knowledge)
Addresses a discipline as a school subject (school knowledge), and hence a reference system that is not restricted to the sciences, but involves diverse components (pedagogical, moral, political, cultural, economic, etc.)

\section{Consequences}

Leads to the production of new disciplines by various means
Leads to the creation of complementary links between school disciplines

cation by integrating the following:

- The vocational project (a logic of action) that underlies training and gives it legitimacy;

- The development of the required professional skills and competencies.

The vocational training process consequently cannot remain at the interdisciplinary 
level (interrelationship between knowledges). Instead, it requires the use of knowledge that could be described as a disciplinary. This knowledge consists of social practices of reference that are dissociated from professional actions and that interact dynamically with theoretical knowledge to guide professional action. Professional training therefore concerns not only disciplinary knowledge and other certified knowledge, but also social practices of reference, made up of explicit and implicit (incorporated) skills and competencies. What is required, in sum, is transdisciplinarity.

\subsection{Foundational Principles for School Interdisciplinarity}

In order to characterize school interdisciplinarity, we suggest six principles for understanding the relationships that need to be established between various school disciplines in order to promote and support an interdisciplinary approach in teaching practices.

\subsubsection{There Can Be No Interdisciplinarity without School Disciplines}

The first principle is that there can be no interdisciplinarity without disciplinarity, that is, without formalized cognitive contents, and without their related instrumental and procedural methods, which we refer to in the educational jargon as "learning processes," i.e., methodological processes that make it possible to construct the knowledge prescribed by the curriculum, to experiment it, to resolve it, to communicate it. Although this might be construed as stating the obvious, we would like to recall, following Newell (1998, 1990), Petrie (1992) and Wineburg and Grossman (2000), that reflection on interdisciplinarity is only meaningful in a disciplinary context and that it "presupposes at least two reference disciplines as well as the presence of reciprocal action" (Germain, 1991: p. 143). The term "interdisciplinarity" itself makes this relationship as a requirement: "inter-disciplinarity" subsumes "disciplinarity"! Numerous definitions of interdisciplinarity that have been researched attest to this position by admitting, at the very least, some kind of relationship between various core components of at least two disciplines, i.e., subjects, contents, processes, techniques, etc.

\subsubsection{School Interdisciplinarity It Neither Any of the Earlier Mentioned Trends, Nor a Mere Addition of Disciplinary Elements}

The second principle is that interdisciplinarity is not based on a cumulative perspective, just as a house is more than just a pile of bricks, to paraphrase a metaphor from Poincaré. Indeed, interdisciplinarity is incompatible with the tendency to believe that mere physical proximity between people-in this case teachers of different subjects-would be enough to make an educational activity interdisciplinary. Nor is interdisciplinarity compatible with an "additive" vision of disciplines and content. Moreover, it is insufficient to acknowledge the multidimensionality of a real-life situation and the possibility of interpreting it in different ways to bring about interdisciplinarity. The fact that students may be taking a course in one or more other disciplines does not make their education interdisciplinary; at first glance, in any case, we are dealing with multidisciplinary, if not eclectic, education. Nor does a field trip to a farm, and the subsequent use 
of this theme to produce activities in French, mathematics, science, arts, etc., make the approach interdisciplinary. In this case we are dealing with pseudo-interdisciplinarity that is in fact pluridisciplinary in nature. Gusdorf (1967) refers to this frequent "magical mentality" toward interdisciplinarity as an erroneous view that consists in "bringing together specialists from different areas believing that such an encounter would be sufficient to establish a common ground and common language between these individuals who, in fact, have nothing in common" (p. 1089).

\subsubsection{Interdisciplinarity Is Only a Means to an End, Namely the Integration of Learning Processes and Knowledge}

The third principle, and perhaps the most important in our view, is that interdisciplinarity in education belongs to the means, rather than the ends. The aim of interdisciplinarity is the integration of learning processes and the integration of the resulting knowledge. The purpose of using interdisciplinarity is to foster the mobilization of knowledge and processes with a view to realizing and successfully carrying out an action. In other words, it is to promote and facilitate students' integration of integrating processes and integrated knowledge, as well as their mobilization and application of these elements inreal-life situations. It therefore requires the establishment of integrative approaches by the teacher, and not the imposing of an integrated curriculum where the integrating process itself has already been established from outside, from above, by the designers of the curriculum, textbooks or activities.

Interdisciplinarity consequently requires the adoption of a socio-constructivist epistemological posture, given that it requires that learning subjects obtain recognition and assert themselves as knowledge producers, and requires that this conceptualization process be part and parcel of the social context. Students' experience of reality is then no longer a representation of the world "as it is" but rather, as Stengers (1993) aptly states, "a risky invention" (p. 62). This is why it is indispensable for the teacher to introduce the conditions deemed favourable to support and guide students' implementation of an interdisciplinary approach to the cognitive questions that are addressed. At the same time, however, it must be kept in mind that integration is above all a cognitive process that must be performed by the students and not the teacher or the curriculum.

\subsubsection{Interdisciplinarity Conceives All School Disciplines as Important and Complementary in Constructing and Understanding Reality}

As Haynes (2002), points out. "No disciplinary viewpoint is inherently or universally true or superior to others" (p. xv). School interdisciplinarity must be understood-and this is the fourth principle-from a relational standpoint, since, to achieve learning, it strives to establish exchanges, connections, and complementary links between school disciplines. This is why it is important to move beyond the views, at first glance antithetical, between theoretical, methodological, instrumental, and critical interdisciplinarities (Klein, 2010) in the school context. Indeed, each discipline in the curriculum exhibits these features. The disciplines should be used in complementary fashion, particularly to avoid extreme practices such as Platonic pure ideas or a mere technicist application. Hermerén (1985) further notes the complementarity that is needed, from a 
knowledge integration perspective, between knowing "that," associated with school interdisciplinarity, and knowing "how," associated with instrumental interdisciplinarity, i.e. between the knowledge he describes as propositional (declarative knowledge) and operational knowledge (procedural knowledge). The principle of equality and complementarity between different disciplinary contents is indispensable; moreover, it stands in contrast to a distinction between primary disciplines, seen as more important, and secondary disciplines, seen as inferior. Instead, it suggests the importance of taking into account the specific identity and functions of each mobilized discipline and its contributions.

\subsubsection{Interdisciplinarity Must Combine Three Complementary Logics}

We have recalled the existence of three different readings of interdisciplinarity. These readings stem from distinct social and cultural contexts. However, as a fifth principle, these three logics of meaning, functionality, and affectivity are complementary and should be interwoven when using interdisciplinary approaches in teaching practices. Otherwise put, interdisciplinarity requires the mind, the hand, and the heart, meaning a strong interrelationship between the cognitive (or epistemological), practical (or pragmatic and social), and human (ontological) dimensions, which, in our view, are fundamental components of human beings and should be at the core of any educational process.

\subsubsection{Interdisciplinarity Requires Collaboration between Teachers of Different School Disciplines}

Finally, the sixth and final principle we would like to suggest is that it is no longer possible today to truly master several disciplines. The era of Giovanni Pico della Mirandola, who in the 15th century set out to conquer all existing knowledge, is long gone. What is needed instead is to pool disciplinary competencies. Consistent with Bernstein (1971, 1975), an interdisciplinary approach based on integrated intervention by a teaching team will tend toward an integrating curriculum, characterized by a system of open contents and an "ample education," as opposed to a compartmentalized curriculum based on a hierarchy of disciplines and a rigid and opaque system of closed-off contents. Numerous authors (Crawford Burns, 2002; Davis, 1995; Fourez, 1994, 1998; Hasni, Lenoir, Larose et al., 2008; Klein \& Newell, 1996; Wentworth \& Davis, 2002; Wineburg \& Grossman, 2000) have shed light on the need for team teaching, which must be undertaken in a spirit of genuine collaboration. In interdisciplinary education, team teaching is required because solving a problem, addressing a question, or carrying out a project all require complementary processes, cognitive contents from different disciplines, etc. Crawford Burns (2002) stresses that "interdisciplinary teams should consider the needs and interests of students as well as the essential content and processes in each discipline and their application to authentic tasks" (p. 68).

\section{By Way of Synthesis: A Definition of School Interdisciplinarity}

In light of the various clarifications we have suggested regarding interdisciplinarity, we 
would like to suggest the following definition: school interdisciplinarity is the action of putting two or more school disciplines into relation on the curricular, cognitive, and operational levels, leading to the establishment of complementarity or cooperative links, interpenetration, or reciprocal action from various standpoints (the aims, objects of study, concepts and notions, learning approaches, technical abilities, etc.). These interactions are aimed at promoting human beings' integration of processes and knowledge. In teaching-learning practices, the teacher's role is to establish the conditions judged to be the best, the most appropriate, to promote and support student learning processes. To draw on interdisciplinarity at school is to introduce conditions that are normally favorable to human beings' implementation of integrating processes by mobilizing various and interrelated disciplinary angles. For, indeed, it is not the teacher who must do the integrating, but the students. They are the actors who will do the integrating, insofar as the two following basic conditions are met: first, examining the principal elements of school disciplines and their structure (conceptual knowledge and disciplinary processes) with a view to identifying interdisciplinary perspectives; and, second, implementing teaching-learning situations that require the construction of conceptual knowledge from two or more school disciplines and that require the complementary use of different learning methods.

As a result, rather than tending toward a merging of disciplines, an electic addition of knowledge elements, a thematic pseudo-interdisciplinarity, or a hegemony of one school discipline over the others, interdisciplinary practices involve relationships that foster mutual dependence between disciplines, free of any dominance or neglect. They are based on a consideration of the educational aims pursued, acknowledging the wealth of complementary links and of real and essential interrelationships between cognitive contents and methods, which are necessary in order to construct, express and interact with human, social, and natural reality. In a school context, the interdisciplinary perspective therefore requires an open relationship between cognitive and practical dimensions, but this relationship must also introduce the affective dimension. This brings us back to the idea of the mind, the hand and the heart, insofar as reason (reflected-on knowledge) mediates between the heart (empirical human dimension) and the hand (operational dimension).

\section{Conclusion}

To conclude, we would like to bring attention to a few aspects which appear essential, in our view, when contemplating the use of interdisciplinarity in school. We have clearly distinguished school interdisciplinarity from other types of interdisciplinarity. Owing to its specific features, this type of interdisciplinarity requires that the knowledge stemming from different school subjects be explicitly addressed and treated to enable learning in connection with various learning situations (problems, projects, compelling scientific or current societal question, etc.). In short, it is important to take into account the purposes and the specific identities of school disciplines in any interdisciplinary classroom approach. 
This is why school interdisciplinarity can under no circumstances be an end in itself: "on an educational level, one can no longer interpret interdisciplinarity without referring to the concept of integration" (Lenoir \& Klein, 2010: p. xviii). This is because its aim is to enable students to develop integrative cognitive processes and the cognitive integration of the knowledge that is gained. We thus consider that the notion of integration must include a dynamic and constructive outlook on learning, one that is meaningful and necessitates the use of cognitive elements from different school disciplines, as well as complementary and interrelated scientific processes. Moreover, it requires the realization of a set of principles that ensure it will pursue objectives that are complex, but accessible to students thanks to the mediation of teachers.

It must also be emphasized that teaching curricula have undergone substantial change over the past decades. Some have grouped together school subjects into subject domains (e.g., physics, chemistry and biology, or history and geography). Even more importantly, they have opened up to questions directly connected to social preoccupations, i.e., to peace, health, civic, environmental, and other types of education. In addition, today's curricula stress a strong contextualization of teaching-learning situations, to root them in experienced realities. These pragmatic and/or cultural necessities (social practices of reference) consequently call for transdisciplinarity.

Academically and epistemologically speaking, the OECD publication (Apostel, Berger, Briggs, \& Michaud, 1972) is an essential reference, as Klein $(1990,2010)$ attests. As with the notion of interdisciplinarity, beyond the many distinctions that can be made ${ }^{2}$, the notion of transdisciplinarity can be approached either as an epistemological problem involving the question of meaning-which is clearly the position explicitly adopted, for example, by Resweber $(1998,2000)$ who sees it as a metalanguage-or as an empirical problem (Klein, 1996) involving the question of functionality and pragmatic preoccupations. In the latter case, the notion is assuredly animated by a cross-cutting perspective that posits the need to use conceptual or methodological tools in order to find an operational response to a problematic situation that requires the contributions of several disciplines, and that transcends all of them. Morin (1990) suggests that transdisciplinarity be considered not as an approach that makes it possible to "distinguish, separate, oppose, and hence relatively disconnect these scientific areas, but rather than can put them into dialogue without producing a reduction" (p. 127), to be able to "account for the multidimensional nature of all realities that are studied" (Ibid., p. 309). Such an orientation rests on the principle of a dialogue and the quest for cooperation and coexistence between the disciplines. It is no longer based on the secular and hierarchical model of the tree of science, but rather requires an educational conceptiongeared toward the production of translators and mediators who are able to carry out this dialogue and, as a result, who are able to pose and construct questions in their

\footnotetext{
${ }^{2}$ We refer the reader to the Kokelmans (1998) analysis of the three main currents of interdisciplinary interpretation and of four currents of transdisciplinary interpretation. Also of interest is the collective work edited by Klein, Grossenbacher-Mansuy, Häberli, Bill, Scholz and Welti (2001), which deals with transdisciplinarity from a research perspective as "a new form of learning and problem solving involving cooperation among different parts of society and academia in order to meet complex challenges of society” (p. 7).
} 
complexity and hence expand the scope of their understanding.

In basic education, it is consequently important to define transdisciplinarity by putting the focus on learning processes, i.e., by taking into account its cross-cutting function. Transdisciplinarity in school, in our view following the conception suggested by Fourez, Maingain and Dufour (2002), above all resides in transferring concepts, methods, procedures, cognitive models, etc., from one disciplinary field to another. For example, this can be the transfer of the concept of force from the field of science to that of humanities, or the transfer of the competency of writing an informative text in the language of instruction to writing an experiment report in science. The idea is a crosscutting mobilization that plays out in the context of a project, which is especially supported by the competency-based approach. This "nomadism," to borrow an expression from Stengers (1987), nevertheless, and especially in secondary school, requires historical and epistemological illumination to shed light on the migration that took place, as well as the related cognitive impacts and changes in meaning that are involved. This is why the transdisciplinary process must be closely supervised by the teacher or, better yet, by a group of teachers.

We also assign another feature to transdisciplinarity, namely that it takes into account common sense knowledge and practices that accompany ways of thinking and acting in everyday life; what is needed is to anchor teaching-learning situations in the complexity of life. When, beyond interdisciplinary links, teaching-learning processes draw on common-sense practices used in everyday life (a disciplinary knowledge, routines, ways of doing things, life experiences, action-based knowledge, etc.) - which are so valuable, as shown for instance by Bourdieu (1980) and Pastré (2008), for supporting these processes and constructing the meaning of action-we describe this type of transdisciplinarity as circumdisciplinarity (from the Latin circum, "around", adverbial accusative of circus, "circle") because it encompasses experiential practices and knowledge (Lenoir, 2000; Lenoir, Larose, \& Dirand, 2006). Hence, in these teaching-learning activities, one finds more than interdisciplinarity.

Finally, whether a curricular conception and its resulting practices are interdisciplinary or transdisciplinary in nature, we would like to recall the necessity, in basic education, of never losing sight of the need for a close connection between the theoretical, methodological, instrumental, and critical interdisciplinarities discussed by Klein (2010). All learning requires these four closely interrelated components, without which neither integrative processes, nor the integration of knowledge, would be possible. $\mathrm{Ne}$ glecting the theoretical component leads to leaving out cognitive content and its integration; neglecting the methodological component, to leaving out the learning processes (integrative operational processes); neglecting the instrumental component, to leaving out the tools needed to implement these processes; and neglecting the critical component, to leaving out the ability to distance oneself from a studied reality in order to understand it.

It must be kept in mind that the foremost mission of basic (primary and secondary) education is to educate individuals who are capable of living and finding fulfilment in 
society, while being able to understand the world in which they live and being able to act on it in a thought-out and critical way. As a result, even if they must adapt to the realities and requirements of our times, primary and secondary school curricula should not fall into an exacerbated individualistic utilitarianism in their attempt to provide young generations with basic human and social education that is rich, diversified, and open. In sum, we must conceive the education of young people from an emancipatory perspective and it is our belief that the inter- and transdisciplinary approaches can significantly contribute to reaching this goal.

\section{References}

Ansart, P. (1990). Pluralisation des savoirs et formation scientifique (Pluralization of Knowledges and Scientific Formation). In G. Racette, \& L. Forest (Eds.), Pluralité des enseignements en sciences humaines à l'université (Plurality of Teachings in Human Sciences at the University) (pp. 21-29). Montreal: Noir sur blanc.

Apostel, L., Berger, G., Briggs, A.,\& Michaud, G. (1972). L'interdisciplinarité. Problèmes d'enseignement et de recherche dans les universités (Interdisciplinarity. Teaching and Research Problems in the Universities). Paris: OECD/Centre for Educational Research and Innovation.

Baillat, G. \& Niclot, D. (2010). In Search of Interdisciplinarity in Schools in France: From Curriculum to Practice. Issues in Integrative Studies, 28, 170-207.

Bernstein B. (1971a). Class, Codes and Control. London: Routedge \& Kegan Paul. http://dx.doi.org/10.4324/9780203014035

Bernstein, B. (1971b). On the Classification and Framing of Educational Knowledge. In M. F. D. Young (Ed.), Knowledge and Control. New Directions for the Sociology of Education (pp. 4769). London: Collier-Macmillan.

Bisault, J. (2011). Contribution à l'élaboration curriculaire d'une éducation scientifique à l'école primaire. Modélisation des moments scolaires à visée scientifique (Contribution to the Curricular Elaboration of a Scientific Education at the Primary School. Modelling of School Moments with Scientific Aim). Thesis for the Authorization to Manage Researches, Cachan: École normale supérieure de Cachan.

Boix-Mansilla, V. (2010). Learning to Synthesize: The Development of Interdisciplinary Understanding. In R. Frodeman, J. T. Klein, \& C. Mitcham (Eds.), The Oxford Handbook of Interdisciplinarity (pp. 288-306). Oxford: Oxford University Press.

Boix-Mansilla, V., \& Lenoir, Y. (2010). Interdisciplinarity in United States Schools: Past, Present, and Future. Issues in Integrative Studies, 28, 1-28.

Bourdieu, P. (1980). Le sens pratique (The Practical Sense). Paris: Minuit.

Clarke, J. H., \& Agne, R. M. (1997). Interdisciplinary High School Teaching: Strategies for Integrated Learning. Boston, MA: Allyn \&Bacon.

Clausen, K., \& Drake, S. (2010). Interdisciplinary Practices in Ontario: Past, Present, and Future. Issues in Integrative Studies, 28, 69-108.

Crawford Burns, R. (2002). Interdisciplinary Teamed Instruction. In J. T. Klein (Ed.), Interdisciplinarity Education in K-12 and College. A Foundation for K-16 Dialogue (pp. 47-69). New York, NY: College Board Publications.

Davis, J. R. (1995). Interdisciplinary Courses and Team Teaching. New Arrangements for Learning. Phoenix, AZ: American Council on Education/The Oryx Press.

Durkheim, M. (1969). L'évolution pédagogique en France (The Pedagogical Evolution in France). 
Paris: Presses Universitaires de France.

Fazenda, I. C. A. (1994). Interdisciplinariedade: História, teoria e pesquisa. Campinas, SP: Papirus Editora.

Fazenda, I. C. A. (1995). Critical-Historical Review of Interdisciplinary Studies in Brazil. Association for Integrative Studies Newsletter, 17, 1-9.

Fazenda, I. C. A. (1998). La formation des enseignants pour l'interdisciplinarité: Synthèse de recherches effectuées au Brésil (Teachers Education for Interdisciplinarity: Synthesis of Researches Made in Brazil). Revue des Sciences de L'éducation, XXIV, 95-114. http://dx.doi.org/10.7202/031963ar

Fogarty, R. (1991). How to Integrate the Curricula. Palatine, IL: IRI/Skylight Publishing.

Fogarty, R. (1993). Integratinge the curricula. Palatine, IL: IRI/Skylight Publishing.

Fourez, G. (1994). Alphabétisation scientifique et technique. Essai sur les finalités de l'enseignement des sciences (Scientific and Technic Alphabetization. Essay on the Aims of the Sciences Teaching). Bruxelles: De Boeck Université.

Fourez, G. (1998). Se représenter et mettre en œuvre l'interdisciplinarité à l'école (To Represent oneself and Implement Interdisciplinarity at School). Revue des sciences de l'éducation, XXIV, 31-50. http://dx.doi.org/10.7202/031960ar

Fourez, G., Maingain, A., \& Dufour, B. (2002). Approches didactiques de l'interdisciplinarité (Didactic Approaches of Interdisciplinarity). Bruxelles: De Boeck Université.

Frazee, B., \& Rudnitski, R. A. (1995). Integrated Teaching Methods: Theory, Classrooms Applications, Field-Based Connections. Albany, NY: Delmar.

Germain, C. (1991). Interdisciplinarité et globalité: Remarques d'ordre épistémologique (Interdisciplinarity and Global Nature: Remarks of Epistemological Order). Revue des Sciences de l'éducation, XVII, 142-152. http://dx.doi.org/10.7202/900691ar

Gusdorf, G. (1967). Les sciences de l'homme sont-elles des sciences humaines? (Are the Human Sciences Human Sciences?). Strasbourg: Université de Strasbourg, Faculté des Lettres.

Hasni, A. (2011). Problématiser, contextualiser et conceptualiser en sciences: point de vue d'enseignants du primaire sur leur pratique de classe (Problematize, Contextualize and conceptualize in Sciences: Primary Teachers' Point of View on Their Practices). In A. Hasni, \& G. Baillat (Eds.), Pratiques d'enseignement des sciences et technologies: Regards sur la mise en œuvre des réformes curriculaires et sur le développement des compétences professionnelles des enseignants (Practices of the sciences and the technologies teaching: Looks on the implementation of the curriculum reforms and on the development of the professional competencies of the teachers) (pp. 105-140). Reims: Presses Universitaires de Reims.

Hasni, A., \& Lenoir, Y. (2001). La place de la dimension organisationnelle dans l'interdisciplinarité: Les facteurs influençant les pratiques de recherche et d'enseignement (Place of the Organizational Dimension in Interdisciplinarity: Factors Influencing Practices of Research and Teaching). In Y. Lenoir, B. Rey, \& I. Fazenda (Eds.), Les Fondements de L'interdisciplinarité dans la Formation à L'enseignement (The Foundations of Interdisciplinarity in Teaching Education) (pp. 179-204). Sherbrooke: Éditions du CRP.

Hasni, A., Lenoir, Y., Larose, F., Samson, G., Bousadra, F., \& Dos Santos, C. (2008). Enseignement des sciences et technologies et interdisciplinarité: Point de vue d'enseignants du secondaire au Québec (Sciences and Technologies Teaching and Interdisciplinarity: Teachers' Point of View of High School in Quebec). In A. Hasni, \& J. Lebeaume (Eds.), Interdisciplinarité et Enseignement Scientifique et Technologique (Interdisciplinarity and Sciences and Technologies Teaching) (pp. 75-110). Sherbrooke-Lyon: Éditions du CRP/INRP.

Haynes, C. (2002). Laying a Foundation for Interdisciplinary Teaching. In C. Haynes (Ed.), In- 
novations in Interdisciplinary Teaching (pp. xi-xxii). Westport, CT: The Oryx Press/ American Council on Education.

Hermerén, G. (1985). Interdisciplinarity Revisited-Promises and Problems. In L. Levin, \& I. Lind (Eds.), Interdisciplinarity Revisited: Re-Assessing the Concept in the Light of Institutional Experience (pp. 15-25). Stockholm: Oecd/Ceri, Swedish National Board of Universities and Colleges, Linköping University.

Honneth, A. (2013). Du désir à la reconnaissance. La fondation hégélienne de la conscience de soi (From Desire to Recognition. The Hegelian Foundation of the Self-Awareness). In A. Honneth (Ed.), Ce que social veut dire. I. Le déchirement du social (What Social Means. 1. The Tearing of the Social) (pp. 84-107). Paris: Gallimard.

Jacobs, H. H. (1989). Interdisciplinary Curriculum: Design and Implementation. Alexandria, VA: Association for Supervision and Curriculum Development.

Klein, J. T. (1990). Interdisciplinarity: History, Theory, and Practice. Detroit, MI: Wayne State University Press.

Klein, J. T. (1996). Crossing Boundaries Knowledge, Disciplinarities, and Interdisciplinarities. Charlottesville, VI: University Press of Virginia.

Klein, J. T. (2002). Introduction: Interdisciplinarity Today: Why? What? and How? In J. T. Klein (Ed.), Interdisciplinarity Education in K-12 and College. A Foundation for K-16 Dialogue (pp. 1-17). New York, NY: College Board Publications. http://dx.doi.org/10.1053/mda.2001.25961

Klein, J. T. (2010). A Taxonomy of Interdisciplinarity. In R. Frodeman, J. T. Klein, \& C. Mitcham (Eds.), The Oxford Handbook of Interdisciplinarity (pp. 15-30). Oxford: Oxford University Press.

Klein, J. T., \& Newell, W. H. (1996). Advancing Interdisciplinary Studies. In J. G. Gaff, J. L. Ratcliff, \& Associates (Eds.), Handbook of the Undergraduate Curriculum. A Comprehensive Guide to Purposes, Structures, Practices, and Change (pp. 393-415). San Francisco, CA: JosseyBass.

Klein, J. T., Grossenbacher-Mansuy, W., Häberli, R., Bill, A., Scholz, R. W. \&Welti, M. (2001). Transdisciplinarity: Joint Problem Solving among Science, Technology, and Society. Basel: Birkhäuser Verlag. http://dx.doi.org/10.1007/978-3-0348-8419-8

Kliebard, H. M. (1992). Forging the American Curriculum. Essays in Curriculum History and Theory. New York, NY-London: Routledge.

Kojève, A. (1947). Introduction à la lecture de Hegel. Leçons sur la phénoménologie de l'esprit professées de 1933 à 1939 à l'École des Hautes-Études réunies et publiées par Raymond Queneau (Introduction to the Reading of Hegel. Lessons on the Phenomenology of the Spirit Professed from 1933 Till 1939 at the School of the Hautes-Studies Gathered and Published by Raymond Queneau). Paris: Gallimard.

Kokelmans, J. J. (1998). Why Interdisciplinarity? In W. H. Newell (Ed.), Interdisciplinarity. Essays from the Literature. New York, NY: The College Board.

Lacan, J. (1966). Écrits 1 (Writings 1). Paris: Seuil.

Lenoir, Y. (1999). Interdisciplinarité (Interdisciplinarity). In J. Houssaye (Ed.), Questions pédagogiques. Encyclopédie historique (Educational Questions. Historic Encyclopedia) (pp. 291-314). Paris: Hachette.

Lenoir, Y. (2000). Formation à l'enseignement et interdisciplinarité: Un mythe ou une exigence? Dépasser l'interdisciplinarité et penser circumdisciplinarité (Teaching Education and Interdisciplinarity: A Myth or a Requirement? To Exceed the Interdisciplinarity and Think Circumdisciplinarité). European Journal of Teacher Education, 23, 289-298.

http://dx.doi.org/10.1080/02619760120049166 
Lenoir, Y. (2002). Les réformes actuelles de la formation à l'enseignement en France et aux ÉtatsUnis: Éléments de mise en perspective socio-historique à partir du concept d'éducation (The Current Reforms of the Teaching Education in France and in the United States: Elements of Put in Perspective Socio-History from the Educational Concept). Revue Suisse des Sciences de L'éducation, 24, 91-126.

Lenoir, Y. (2005). Três interpretações da perspectiva interdisciplinar em educação em função de três tradições culturais distintas. Revista e-curriculum, 1, 1-24.

Lenoir, Y., \& Hasni, A. (2004). La interdisciplinaridad: por un matrimonio abierto de la razón, de la mano y del corazón. Revista Iberoamericana de Educación, 35, 167-185.

Lenoir, Y., \& Klein, J. (2010). Interdisciplinarity in Schools: A Comparative View of National Perspectives. Issues in Integrative Studies, 28, 1-331.

Lenoir, Y., Hasni, A., \& Froelich, A. (2015). Curricular and Didactic Conceptions of Interdisciplinarity in the Field of Education: A Socio-Historical Perspective. Issues in Interdisciplinary Studies, 33, 39-93.

Lenoir, Y., Larose, F., \& Dirand, J.-M. (2006). Formation professionnelle et interdisciplinarité: quelle place pour les savoirs disciplinaires? (Vocational Training and Interdisciplinarity: Which Places for the Disciplinary Knowledges). In B. Fraysse (Ed.), Professionnalisation des élèves ingénieurs (Professionalization of the Pupils Engineers) (pp. 13-35). Paris: L'Harmattan.

Lenoir, Y., Rey, B., \& Fazenda, I. (2001). Les fondements de l'interdisciplinarité dans la formation à l'enseignement (The Foundations of the Interdisciplinarity in Teaching Education). Sherbrooke: Éditions du CRP.

Lenoir, Y.,\&Hasni, A. (2010). Interdisciplinarity in Quebec Schools: 40 Years of Problematic Implementation. Issues in Integrative Studies, 28, 238-294.

Long, J., Moran, W., \& Harris, J. (2010). Following the Yellow Brick Road: Interdisciplinary Practices in the Land of Oz. Issues in Integrative Studies, 28, 28-68.

Miñana Blasco, C. (2001). Interdisciplinariedad y currículo. Construcción de proyectos escuelauniversidad. Bogotá: Universaidad Nacional de Colombia.

Morin, E. (1977-1991). La méthode (The Methodology) (4 Vol.). Paris: Seuil.

Morin, E. (1990). Science avec conscience (Science with Conscience) (2nd ed.). Paris: Seuil.

Newell, W. H. (1990). Interdisciplinary Curriculum Development. Issues in Integrative Studies, 8, 69-86.

Newell, W. H. (1998). Interdisciplinary Curriculum Development. In W. H. Newell (Ed.), Interdisciplinarity. Essays from the Literature (pp. 51-65). New York, NY: The College Board.

Newell, W. H. (2001). A Theory of Interdisciplinary Studies. Issues in Integrative Studies, 19, 126.

Pastré, P. (2008). Apprentissage et activité (Learning and Activity). In Y. Lenoir, \& P. Pastré (Eds.), Didactique professionnelle et didactiques disciplinaires en débat: un enjeu pour la professionnalisation des enseignants (Professional Didactics and Disciplinary Didactics in Debate: A Stake for the Professionalization of the Teachers) (pp. 53-79). Toulouse: Octarès Éditions.

Petrie, H. G. (1992). Interdisciplinarity Education: Are We Face with Insurmountable Opportunities? Review of Research in Education, 18, 299-333.

Pollard, A., \& Tann, S. (1987). Reflective Teaching in the Primary School. A Handbook for the Classroom. London: Cassell Education.

Resweber, J.-P. (1998). Disciplinarité, transdisciplinarité et postures du sujet (Disciplinarity, Transdisciplinarity and Postures of the Subject). In C. Maillard, \& A. Bothorel-Witz (Eds.), Du dialogue des disciplines. Germanistique et interdisciplinarité (Of the Dialogue of the Disciplines. 
Germanistique and Interdisciplinarity) (pp. 19-35). Strasbourg: Presses Universitaires de Strasbourg.

Resweber, J.-P. (2000). Le pari de la transdisciplinarité. Vers l'intégration des savoirs (The Bet of the Transdisciplinarity. Towards the Integration of the Knowledges). Paris: L'Harmattan.

Rieber, R. W., \& Carton, A. S. (1987). The Collected Works of L. S. Vygotsky. Vol. 1: Problems of General Psychology Including the Volume Thinking and Speech (Translated by N. Minick). New York, NY: Plenum Press.

Rodriguez, J. G., \& Miñana Blasco, C. (2010). Interdisciplinary and Research on Local Issues in Schools: Policies and Experiences from Colombia. Issues in Integrative Studies, 28, 109-137.

Sachot, M. (1993). La notion de "dicipline scolaire": éléments de constitution (The Notion of "School Discipline: Constituent Elements". In J.-P. Clément, \& M. Herr (Eds.), L'identité de l'éducation physique scolaire au XXe siècle: Entre l'école et le sport (The Identity of the School Physical Education in the XXth Century: Between School and Sport) (pp. 127-147). Clermont-Ferrand: Éditions Afraps.

Segovia, I., Lupiáñiez, J. L., Molina, M., González, F., Miñán, A., \& Real, I. (2010). The Conception and Role of Interdisciplinarity in the Spanish Education System. Issues in Integrative Studies, 28, 208-237.

Spinoza, B. (1842). III. De l'origine et de la nature des passions (Of the Origin and the Nature of the Passions). In L'éthique (trad. Par Saisset) (1st ed., pp. 81-139). 1667.

http://www.spinozaetnous.org

Stengers, I. (1987). D'une science à l'autre. Des concepts nomades (From a Science to the Other One. Nomadic Concepts). Paris: Seuil.

Stengers, I. (1993). L'invention des sciences modernes (The Invention of the Modern Sciences). Paris: La Découverte.

Stichweh, R. (1991). Études sur la genèse du système scientifique moderne (Studies on the Genesis of the Modern Scientific System) (trad. F. Blaise). Lille: Presses Universitaires de Lille.

Tann, S. (1988). Developing Topic Work in the Primary School. London-Philadelphia, PA: The Falmer Press.

Torres Santomé, J. (1998). Glonbalización e Interdisciplinariedad: El curriculo integrado. Madrid: Ediciones Morata.

Vars, G. F. (1993). Interdisciplinary Teaching: Why \& How. Columbus, OH: National Middle School Association.

Wentworth, J., \& Davis, J. R. (2002). Enhancing Interdisciplinarity through Team Teaching. In C. Haynes (Ed.), Innovations in Interdisciplinary Teaching (pp. 16-37). Westport, CT: The Oryx Press/American Council on Education.

Wineburg, S., \& Grossman, P. (2000). Interdisciplinary Currculum. Challenges to Implementation. New York, NY: Teachers College Press.

Young, M. F. D. (1971). An Approach to the Study of Curricula as Socially Organized Knowledge. In M. F. D. Young (Ed.), Knowledge and Control. New Directions for the Sociology of Education (pp. 19-46). London: Collier Macmillan. 
Submit or recommend next manuscript to SCIRP and we will provide best service for you:

Accepting pre-submission inquiries through Email, Facebook, LinkedIn, Twitter, etc. A wide selection of journals (inclusive of 9 subjects, more than 200 journals)

Providing 24-hour high-quality service

User-friendly online submission system

Fair and swift peer-review system

Efficient typesetting and proofreading procedure

Display of the result of downloads and visits, as well as the number of cited articles

Maximum dissemination of your research work

Submit your manuscript at: http://papersubmission.scirp.org/

Or contact ce@scirp.org 